\title{
Control of Calcium Homeostasis in Schistosoma mansoni
}

\author{
F Noël ${ }^{+}$, VMN Cunha, CLM Silva, DL Mendonça-Silva
}

\author{
Departamento de Farmacologia Básica e Clínica, ICB, Universidade Federal do Rio de Janeiro, \\ Cidade Universitária, 21941-590 Rio de Janeiro, RJ, Brasil
}

Calcium signalling is fundamental for muscular contractility of Schistosoma mansoni. We have previously described the presence of transport ATPases $\left(\mathrm{Na}^{+}, \mathrm{K}^{+}\right.$-ATPase and $\left(\mathrm{Ca}^{2+}-\mathrm{Mg}^{2+}\right)$-ATPase $)$ and calcium channels (ryanodine receptors - RyR) involved in control of calcium homeostasis in this worm. Here we briefly review the main technics (ATPase activity, binding with specific radioligands, fluxes of ${ }^{45} \mathrm{Ca}^{2+}$ and whole worm contractions) and results obtained in order to compare the distribution patterns of these proteins: thapsigargin-sensitive $\left(\mathrm{Ca}^{2+}-\mathrm{Mg}^{2+}\right)$-ATPase activity and RyR co-purified in $P_{1}$ and $P_{4}$ fractions mainly, which is compatible with a sarcoplasmic reticulum localization, while basal ATPase (along with $\mathrm{Na}^{+}, \mathrm{K}^{+}$-ATPase) and thapsigargin-resistant $\left(\mathrm{Ca}^{2+}-\mathrm{Mg}^{2+}\right)$-ATPase have a distinct distribution, indicative of their plasma membrane localization. Finally we attempt to integrate these contributions with data from other groups in order to propose the first synoptic model for control of calcium homeostasis in $\mathrm{S}$. mansoni.

Key words: Schistosoma mansoni - calcium - ATPase - ryanodine

As for mammals, the control of low cytosolic calcium concentrations appears to be very important in Schistosoma mansoni cell physiology as a whole, and in muscular contractility in particular. The main muscle present in adult worms presents morphologic similarities with the smooth type present in higher animals (Silk \& Spence 1969). On the other hand, species differences exist in relation to the nature of the putative transmitters (worm specific FMRFamide related peptides, e.g. - Day \& Maule 1999) and/or receptors (distinct pharmacological modulation of 5-hydroxytryptamine effects, e.g. - Willcokson \& Hillman 1984) involved in $S$. mansoni contraction. Some years ago, we had no idea of how the worm could maintain a low cytosolic calcium after a contraction induced by such stimuli, so that we initiated studies to investigate the presence of transport ATPases and ion channels present either on plasma membrane or intracellular organelles. In the present communication we re-analyze some of our data, integrate our main contributions with data from other groups in order to propose a synoptic model for the control of cal-

This work was supported by Faperj, CNPq and Finep (Pronex).

Mendonça-Silva and Noël are fellows of Capes and $\mathrm{CNPq}$, respectively.

${ }^{+}$Corresponding author. Fax +55-21-2562.6732. E-mail: fnoel@pharma.ufrj.br

Received 14 May 2001

Accepted 25 June 2001 cium homeostasis in $S$. mansoni, and further add some insight to the phylogenetic importance of these proteins.

\section{MATERIALS AND METHODS}

Preparation of subcellular fractions - About 2000 adult worms (BH strain) were homogenized in a Dounce homogenizer at $4^{\circ} \mathrm{C}$ in $0.25 \mathrm{M}$ sucrose solution $(5 \mathrm{mM}$ Tris-HCl pH 7.4) using three sequences of 10 passes of the pestle. The homogenate was centrifuged to obtain four pellets $\left(\mathrm{P}_{1}, \mathrm{P}_{2}\right.$, $\left.\mathrm{P}_{3}, \mathrm{P}_{4}\right)$ sedimenting respectively at $300 g_{\text {av }}(5 \mathrm{~min})$; $1000 g_{\text {av }}(10 \mathrm{~min}) ; 8000 g_{\text {av }}(10 \mathrm{~min})$ and 100,000 $g_{\text {av }}(1 \mathrm{~h})$. These fractions have been previously characterized by electronic microscopy (Cunha et al. 1988) as heterogeneous $\left(\mathrm{P}_{1}\right)$, nuclear $\left(\mathrm{P}_{2}\right)$, mitochondrial $\left(\mathrm{P}_{3}\right)$ and microsomal $\left(\mathrm{P}_{4}\right)$.

ATPase assays - The experimental conditions for measuring $\left(\mathrm{Ca}^{2+}-\mathrm{Mg}^{2+}\right)$-ATPase activities through the colorimetric dosage of inorganic phosphate have been previously described in details (Cunha et al. 1996).

Binding assays - Classical radioligand binding assays with $\left[{ }^{3} \mathrm{H}\right]$ ouabain and $\left[{ }^{3} \mathrm{H}\right]$ ryanodine were used for labeling $\mathrm{Na}^{+}, \mathrm{K}^{+}$-ATPase and ryanodine receptors (RyR), respectively (Pardon \& Noël 1994, Silva et al. 1998). In both conditions, rapid vacuum filtration on glass fibre filters (Whatman GF/C) was used in order to separate bound and free radioligands.

\section{RESULTS AND DISCUSSION}

Although a small $\mathrm{Na}^{+}, \mathrm{K}^{+}$-ATPase activity had already been reported in $S$. mansoni homogenate (Nechay et al. 1980), we initiated our studies by re- 
investigating this enzyme due to its importance for maintaining membrane potential, sodium gradient and, indirectly, intracellular calcium concentrations (Sweadner 1989). The presence of $\mathrm{Na}^{+}, \mathrm{K}^{+}$-ATPase activities with different sensitivity to ouabain in tegumental and carcass preparations (Noël \& Soares de Moura 1986) and the characterization of two classes of $\left[{ }^{3} \mathrm{H}\right]$ ouabain binding sites in the homogenate (Pardon \& Noël 1994) let us propose the existence of more than one isoenzyme in this worm, just as in mammals. Although very similar to the mammalian enzyme with respect to (physiological) activators (Noël \& Soares de Moura 1986), the worm enzyme exhibited some pharmacological difference being much more resistant to vanadate, the classical inhibitor of P-ATPases (Noël \& Pardon 1989). S. mansoni $\mathrm{Na}^{+}, \mathrm{K}^{+}$-ATPase has not been cloned yet, but a PCR product (SMIV) exhibiting $84 \%$ homology with mammalian $\mathrm{Na}^{+}, \mathrm{K}^{+}$-ATPase has been described (de Mendonça et al. 1995). Later on, we characterized the presence of a calcium pump activity (Cunha et al. 1992) that was mainly related to a Sarco/Endoplasmic Reticulum $\left(\mathrm{Ca}^{2+}-\mathrm{Mg}^{2+}\right)$ ATPase (SERCA). Here too, although (physiological) activation of the enzyme occurred at the same submicromolar concentrations of calcium as for mammalian SERCA, a difference in the pharmacological modulation by thapsigargin, a specific inhibitor of SERCA, was observed (Cunha et al. 1996). In fact when re-expressed in nmol thapsigargin/ enzymatic unit (EU) in order to correct for different quantities of enzyme molecules in the assay (Sagara
\& Inesi 1991), the worm enzyme $\left(\mathrm{IC}_{50}=50 \mathrm{nmol} /\right.$ EU) was about 140-250 fold more resistant to thapsigargin than mammalian enzymes $\left(\mathrm{IC}_{50}=0.2\right.$ $0.35 \mathrm{nmol} / \mathrm{EU}$; Lytton et al. 1991, Mason et al. 1993). A physiological role for this ATPase has recently been confirmed when the full-length SMA2 cDNA clone from S. mansoni was expressed in $\left(\mathrm{Ca}^{2+}-\right.$ $\mathrm{Mg}^{2+}$ )-ATPase-deficient yeast (Talla et al. 1998). A second $\left(\mathrm{Ca}^{2+}-\mathrm{Mg}^{2+}\right)$-ATPase activity, resistant to thapsigargin and cyclopiazonic acid (two selective inhibitors of SERCA) was also reported, that could be located in the plasma membrane (Cunha et al. 1996).

Just as in mammals or invertebrates, stored calcium is supposed to be mobilized from intracellular stores through intracellular calcium channels. We were recently able to characterize the presence of specific binding sites for $\left[{ }^{3} \mathrm{H}\right]$ ryanodine with an affinity similar to the mammalian RyR (Silva et al. 1998). This binding was modulated by $\mathrm{Mg}^{2+}$ and $\mathrm{Ca}^{2+}$ ions as well as by caffeine. Furthermore, the addition of ryanodine induced the contraction of whole worms, in vitro. These data were corroborated by Day et al. (2000) which have showed that caffeine, an agonist of RyR, was able to contract isolated muscle fibres. In this way we may propose that the presence of sarcoplasmic reticulum calcium stores, with both SERCA and RyR, is essencial to support worm contraction. In Table we compare the distribution patterns of both $\left(\mathrm{Ca}^{2+}-\mathrm{Mg}^{2+}\right)$ ATPases (sensitive and resistant to thapsigargin), RyR and basal ATPase. Basal ATPase activity, mea-

TABLE

Distribution patterns of basal ATPase, $\left(\mathrm{Ca}^{2+}-\mathrm{Mg}^{2+}\right)$-ATPases and ryanodine receptors in subcellular fractions from Schistosoma mansoni homogenate

\begin{tabular}{|c|c|c|c|c|}
\hline $\begin{array}{l}\text { Subcellular } \\
\text { Fractions }\end{array}$ & $\begin{array}{c}\text { Basal ATPase } \\
(\%)\end{array}$ & $\begin{array}{c}\left(\mathrm{Ca}^{2+}-\mathrm{Mg}^{2+}\right)-\mathrm{ATPase} \\
\text { Tg-resistant }(\%)\end{array}$ & $\begin{array}{c}\left(\mathrm{Ca}^{2+}-\mathrm{Mg}^{2+}\right) \text {-ATPase } \\
\text { Tg-sensitive }(\%)\end{array}$ & $\begin{array}{c}{\left[{ }^{3} \mathrm{H}\right] \text { ryanodine bound }} \\
(\%)\end{array}$ \\
\hline $\begin{array}{l}\mathrm{P}_{1} \\
\mathrm{P}_{2} \\
\mathrm{P}_{3} \\
\mathrm{P}_{4}\end{array}$ & $\begin{array}{c}26.3 \pm 5.7 \\
* 15.7 \pm 1.9 \\
23.3 \pm 4.7 \\
-34.5 \pm 3.0 \\
n=7\end{array}$ & $\begin{array}{c}-* 50.8 \pm 8.3 \\
-11.0 \pm 4.1 \\
-11.1 \pm 3.9 \\
26.7 \pm 6.4 \\
n=7\end{array}$ & 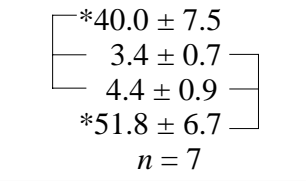 & \begin{tabular}{|c}
$42.3 \pm 6.1$ \\
$5.2 \pm 0.8$ \\
$-7.5 \pm 1.6$ \\
$* 45.0 \pm 5.0$ \\
$n=6$
\end{tabular} \\
\hline
\end{tabular}

$\left(\mathrm{Ca}^{2+}-\mathrm{Mg}^{2+}\right)$-ATPase activity corresponds to the $\mathrm{Mg}^{2+}$-dependent ATPase that is stimulated by micromolar concentrations of free calcium and that has been shown to be responsible for active calcium pumping (Cunha et al. 1988). The thapsigargin-sensitive ( $\mathrm{TgS}$ ) activity was calculated subtracting the thapsigargin-resistant (TgR) activity (measured in the presence of $1 \mu \mathrm{M}$ thapsigargin) from the total $\left(\mathrm{Ca}^{2+}-\mathrm{Mg}^{2+}\right)$-ATPase activity (measured in the absence of thapsigargin). Basal ATPase was measured in the absence of $\mathrm{Ca}^{2+}, \mathrm{Na}^{+}$and $\mathrm{K}^{+}$ions (Cunha et al. 1996). The results are expressed as percent of recovery calculated as follows: $100 \mathrm{X}$ activity or binding (specific activity or binding $\mathrm{X}$ protein content) divided by the sum of the activity or binding of all four $S$. mansoni fractions $\left(\mathrm{P}_{1}-\mathrm{P}_{4}\right)$. Values are means \pm SEM; $n=$ the number of different preparations used in experiments performed in triplicate or quadruplicate. Note that the distribution patterns of $\mathrm{TgS}\left(\mathrm{Ca}^{2+}-\mathrm{Mg}^{2+}\right)-\mathrm{ATPase}$, TgR $\left(\mathrm{Ca}^{2+}-\mathrm{Mg}^{2+}\right)-\mathrm{ATPase}$ and basal ATPase activities are not the same (lines and * show the fractions which present a significant difference in the percent of recovery for each fraction, $\mathrm{P}<0.05$ - ANOVA). On the contrary, distribution patterns for $\left[{ }^{3} \mathrm{H}\right]$ ryanodine binding and thapsigargin-sensitive ATPase activity are not different (the two activities are not significantly different when compared in each fraction, $\mathrm{P}>0.1$ - ANOVA). 
sured in the absence of $\mathrm{Na}^{+}, \mathrm{K}^{+}$and $\mathrm{Ca}^{2+}$ ions, has been shown to share the same pattern of distribution as that of high-affinity binding sites for $\left[{ }^{3} \mathrm{H}\right]$ ouabain, a marker of $\mathrm{Na}^{+}, \mathrm{K}^{+}$-ATPase, when assayed simultaneously in a single preparation (Cunha et al. 1996). In fact, since all our data have been obtained using the same procedures we may compare the recovery of these activities/binding sites along the four subcellular fractions prepared from male adult worm homogenate. Table indicates that thapsigargin-sensitive $\left(\mathrm{Ca}^{2+}-\mathrm{Mg}^{2+}\right)$-ATPase activity and RyR co-purified in $\mathrm{P}_{1}$ and $\mathrm{P}_{4}$ fractions mainly, while basal ATPase (along with $\mathrm{Na}^{+}, \mathrm{K}^{+}$ATPase) and thapsigargin-resistant $\left(\mathrm{Ca}^{2+}-\mathrm{Mg}^{2+}\right)-$ ATPase have a distinct distribution. All these data are compatible with the nature/localization proposed above for these proteins.

The similarity with mammalian systems for controlling calcium concentrations in muscles goes further since we have good evidences for the presence of calcium channels (of the L-type ?) (Fetterer et al. 1980, da Silva \& Noël 1995) and $\mathrm{Ca}^{2+}$-activated $\mathrm{K}^{+}$-channels (Blair et al. 1991) in the plasma membrane that could interact with RyR in order to control muscular tone (Jaggar et al. 1998). Other important participants in calcium signalling are also present in $S$. mansoni since different calcium-binding proteins $(\mathrm{CaBP})$ have been reported: an EF-hand CaBP like calmodulin, the ubiquitous partner of calcium for diverse enzymatic pathways (Thompson et al. 1986) and Sm20, possibly acting as a reservoir for calcium in SR muscle (Stewart et al. 1992). Calreticulin, a non-EF-hand CaBP normally resident in the endoplasmic reticulum, has also been described but seems to be mainly expressed in the digestive gut and genital organs of the worm (Khalife et al. 1994). An overview of all the proteins participating in the control of calcium homeostasis is presented in a cartoon representing a hypothetical smooth muscle cell of S. mansoni (Figure).

Based on the phylogenetic importance of platyhelminths that are the first metazoan group to possess a centralized nervous system, being considered as the link between lower and higher invertebrates (Day \& Maule 1999), we may propose that current systems controlling calcium homeostasis were selected very early in the evolution process and that the presence of different isoforms to perform the same work has to be considered a phylogenetic advantage.

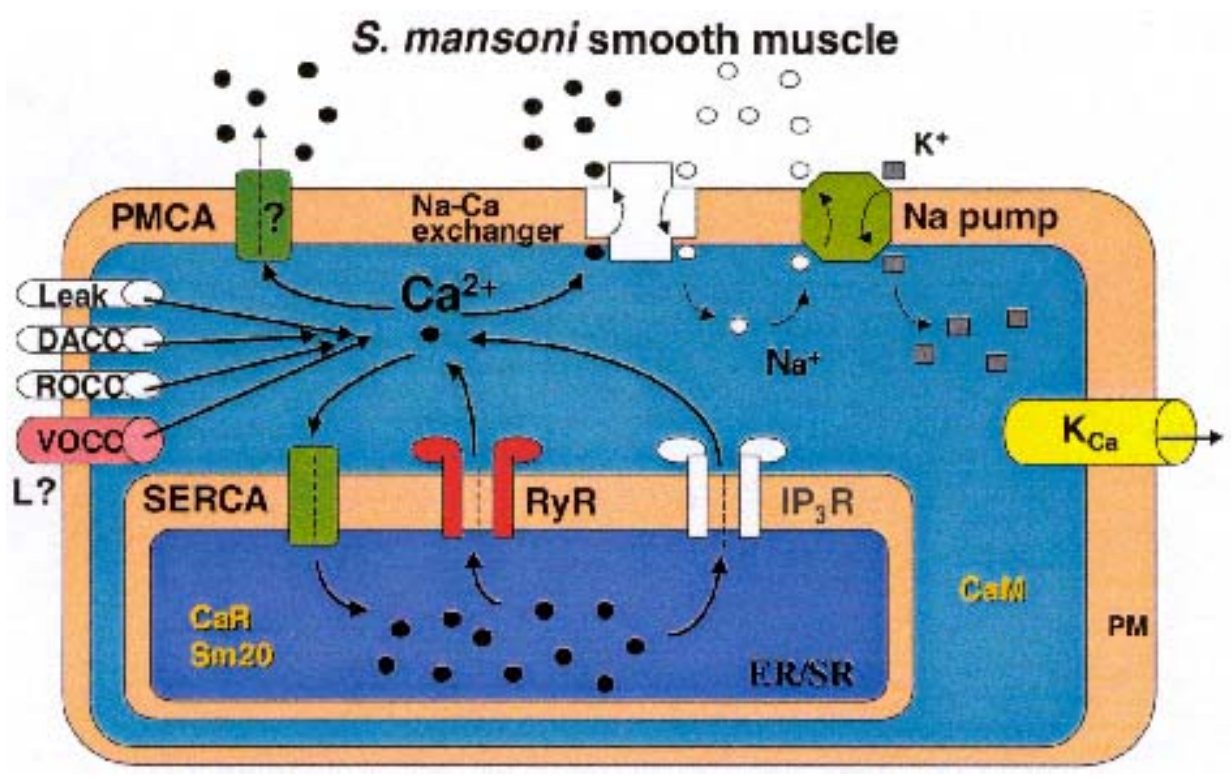

Synoptic view of proteins controlling calcium homeostasis in a putative smooth muscle cell of Schistosoma mansoni. Colored proteins have already been described (see text for explanation) whereas putative proteins not yet described are represented in white. ATPases: PMCA (plasma membrane $\left(\mathrm{Ca}^{2+}-\mathrm{Mg}^{2+}\right)$-ATPase), SERCA (sarco-endoplasmic reticulum $\left(\mathrm{Ca}^{2+}-\mathrm{Mg}^{2+}\right)$-ATPase) and $\mathrm{Na}^{+}$pump $\left(\mathrm{Na}^{+}, \mathrm{K}^{+}\right.$-ATPase). Plasma membrane ion channels: Leak, DOCC (depletionoperated calcium channel), ROCC (receptor-operated calcium channel) and VOCC (voltage-operated calcium channel) for entry of calcium, and $\mathrm{K}_{\mathrm{ca}}$ for extrusion of potassium ions. Intracellular calcium channels: RyR (ryanodine receptors) and $\mathrm{IP}_{3} \mathrm{R}$ (inositol 1,4,5-triphosphate receptors). Calcium Binding Proteins: CaR (calreticulin), SM20 (20-kilodalton calcium-binding protein of S. mansoni) and CaM (calmodulin). PM: plasma membrane. SR/ER: Sarco-Endoplasmic Reticulum 


\section{ACKNOWLEDGEMENTS}

To Dr Lygia dos Reis Corrêa (Instituto Oswaldo Cruz, Rio de Janeiro, Brazil) who kindly provided the infected mice.

\section{REFERENCES}

Blair KL, Day TA, Lewis MC, Bennett JL, Pax RA 1991. Studies on muscle cells isolated from Schistosoma mansoni: a $\mathrm{Ca}(2+)$-dependent $\mathrm{K}+$ channel. Parasitology 102: 251-258.

Cunha VMN, De Souza W, Noël F 1988. A Ca ${ }^{2+}$-stimulated, $\mathrm{Mg}^{2+}$-dependent ATPase activity in subcellular fractions from Schistosoma mansoni. FEBS Letters 241: 65-68.

Cunha VMN, Meyer-Fernandes JR, Noël F 1992. A $\left(\mathrm{Ca}^{2+}-\mathrm{Mg}^{2+}\right)$ ATPase from Schistosoma mansoni is coupled to an active transport of calcium. Mol Biochem Parasitol 52: 167-174.

Cunha VMN, Reis JMA, Noël F 1996. Evidence for the presence of two $\left(\mathrm{Ca}^{2+}-\mathrm{Mg}^{2+}\right)$ ATPases with different subcellular distributions in the human flatworm Schistosoma mansoni. Comp Biochem Physiol 114B: 199-205.

da Silva SP, Noël F 1995. Time-course of the effect of praziquantel on Schistosoma mansoni attachment in vitro: comparison with its effects on worm length and motility. Parasitol Res 81: 544-548.

Day TA, Maule AG 1999. Parasitic peptides! The structure and function of neuropeptides in parasitic worms. Peptides 20: 999-1019.

Day TA, Haithcock J, Kimber M, Maule AG 2000. Functional ryanodine receptor channels in flatworm muscle fibres. Parasitology 120: 417-422

Fetterer RH, Pax RA, Bennett JL 1980. Praziquantel, potassium and 2,4-dinitrophenol: analysis of their action on the musculature of Schistosoma mansoni. Eur J Pharmacol 64: 31-38.

Jaggar JH, Wellman GC, Heppner TJ, Porter VA, Perez GJ, Gollasch M, Kleppisch T, Rubart M, Stevenson AS, Lederer WJ, Knot HJ, Bonev AD, Nelson MT 1998. $\mathrm{Ca}^{2+}$ channels, ryanodine receptors and $\mathrm{Ca}^{2+}$ activated $\mathrm{K}^{+}$channels: a functional unit for regulating arterial tone. Acta Physiol Scand 164: 577-587.

Khalife J, Liu JL, Pierce R, Porchet E, Godin C, Capron A 1994. Characterization and localization of Schistosoma mansoni calreticulin Sm58. Parasitology 108: 527-32.

Lytton J, Westlin M, Hanley, MR 1991. Thapsigargin inhibits the sarcoplasmic or endoplasmic reticulum Ca-ATPase family of calcium pumps. J Biol Chem
226: 17067-17071.

Mason MJ, Mayer B, Hymel LJ 1993. Inhibition of $\mathrm{Ca}^{2+}$-transport pathways in thymic lymphocytes by econazole, miconazole and SKF 96365. Am J Physiol 264: C654-C662.

de Mendonca RL, Beck E, Rumjanek FD, Goffeau A 1995. Cloning and characterization of a putative calcium-transporting ATPase gene from Schistosoma mansoni. Mol Biochem Parasitol 72: 129-39

Nechay BR, Hillman GR, Dotson MJ 1980. Properties and drug sensitivity of adenosine triphosphatases form Schistosoma mansoni. J Parasitol 66: 596-600.

Noël F, Soares de Moura R 1986. Schistosoma mansoni: preparation and characterization of $\left(\mathrm{Na}^{+}+\mathrm{K}^{+}\right)$ATPase from tegument and carcass. Exp Parasitol 62: 298-307.

Noël F, Pardon RS 1989. Vanadate sensitivity of $\mathrm{Na}^{+}, \mathrm{K}^{+}-$ ATPase from Schistosoma mansoni and its modulation by $\mathrm{Na}^{+}, \mathrm{K}^{+}$and $\mathrm{Mg}^{+}$. Life Sci 44: 1677-1683.

Pardon RS, Noël F 1994. Heterogeneity of ouabain binding sites in Schistosoma mansoni: first evidence for the presence of two $\left(\mathrm{Na}^{+}+\mathrm{K}^{+}\right)$ATPase isoforms in platyhelminths. Biochem Pharmacol 47: 331-336.

Sagara Y, Inesi G 1991. Inhibition of the sarcoplasmic reticulum $\mathrm{Ca}^{2+}$ transport ATPase by Thapsigargin at subnanomolar concentrations. J Biol Chem 226: 13503-13506.

Silk MH, Spence IM 1969. Ultrastructural studies of the blood fluke Schistosoma mansoni. III. The musculature. S Afr J Med Sci 34: 11-20.

Silva CLM, Cunha VMN, Mendonça-Silva DL, Noël, F 1998. Evidence for ryanodine receptors in Schistosoma mansoni. Biochem Pharmacol 55: 1531-1535.

Stewart TJ, Smith AL, Havercroft JC 1992. Analysis of the complete sequence of a muscle calcium-binding protein of Schistosoma mansoni. Parasitology 105: 399-408.

Sweadner KJ 1989. Isoenzymes of the $\mathrm{Na}^{+} / \mathrm{K}^{+}$-ATPase. Biochem Biophys Acta 988: 185-220.

Talla E, de Mendonca RL, Degand I, Goffeau A, Ghislain M 1998. Schistosoma mansoni Ca2+-ATPase SMA2 restores viability to yeast $\mathrm{Ca} 2+-\mathrm{ATPase}$-deficient strains and functions in calcineurin-mediated $\mathrm{Ca} 2+$ tolerance. J Biol Chem 273: 27831-27840.

Thompson DP, Chen GZ, Sample AK, Semeyn DR, Bennett JL 1986. Calmodulin: biochemical, physiological, and morphological effects on Schistosoma mansoni. Am J Physiol 251: R1051-1058.

Willcockson WS, Hillman GR 1984. Drug effects on the 5-HT response of Schistosoma mansoni. Comp. Biochem Physiol 77C: 199-203. 